Journal of Government and Political Studies

Volume 4 - NO. 1 - April 2021

P-ISSN: 2614-2120 E-ISSN: 2614-2104

\title{
Membangun Keharmonisan Antara Etnis Lokal Gorontalo dengan Etnis Bali dalam Mewujudkan Negara Multikulturalisme di Desa Tri Rukun Kecamatan Wonosari Kabupaten Boalemo Provinsi Gorontalo dan Implikasinya terhadap Ketahanan Wilayah
}

\author{
Roni Lukum \\ Jurusan Ilmu Hukum dan Kemasyarakatan, \\ Fakultas Ilmu Sosial Universitas Negeri Gorontalo \\ J1. Jend. Sudirman No.6, Kota Gorontalo
}

Received: 14th September 2020; Revised: 09th March 2021; Accepted: 19h March 2021

\begin{abstract}
The research objective is expected to find out how the Tri Rukun village government efforts in building harmony between Gorontalo local ethnicities and Balinese ethnicity in realizing a multiculturalism state and its implications for regional resilience. The research was conducted using a qualitative approach. Based on the results of the study, it shows that the harmonious relationship between the local ethnic Gorontalo and the Balinese is in a very strong qualitative position in realizing a multiculturalism country, because the indicators of competition, acculturation, cooperation, accommodation, assimilation, conflict are not found in Tri Rukun village. Likewise with the indicators of regional resilience, the ideological dimension, the political dimension, the economic dimension, the socio-cultural dimension and the defense and security dimension, there are no threats and obstacles in realizing a multiculturalism state. Thus the results of research in Tri Rukun village show that the condition of regional resilience has a very strong index in building a multiculturalism country where the Tri Rukun village community highly upholds egalitarian attitudes, tolerance, cooperation, autonomy and accommodative attitudes as the principles of a multiculturalism state. Hopefully the achievements of the Boalemo district government will succeed in maintaining the harmonious relationship that has been achieved by the Tri Rukun village government in realizing a multiculturalism country can be maintained.
\end{abstract}

Keywords: multiculturalism; etnic; Gorontalo; Boalemo

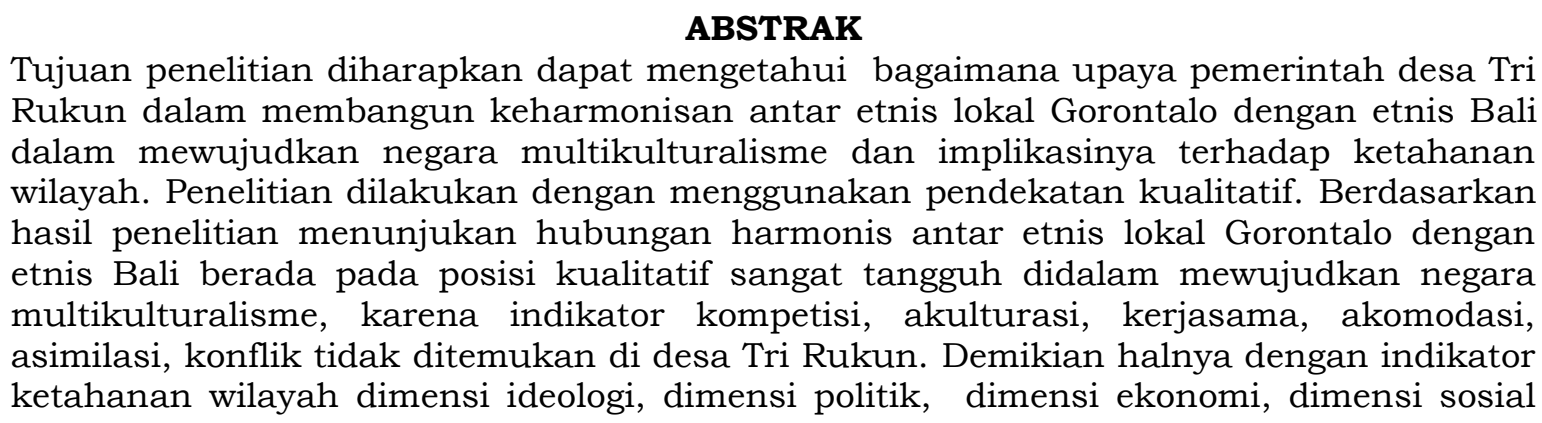


budaya dan dimensi pertahanan dan keamanan tidak ditemukan gangguan ancaman dan hambatan dalam mewujudkan negara multikulturalisme. Dengan demikian hasil penelitian di desa Tri Rukun menunjukan kondisi ketahanan wilayah memiliki indeks sangat tangguh dalam membangun negara multikulturalisme dimana masyarakat desa Tri Rukun sangat menjunjung tinggi sikap egalitarian, sikap toleransi, sikap kerjasama, sikap otonom dan sikap akomodatif sebagai prinsip dari negara multikulturalisme. Semoga prestasi pemerintah kabupaten Boalemo berhasil menjaga hubungan harmonis yang telah dicapai oleh pemerintah desa Tri Rukun dalam mewujudkan negara multikulturalisme dapat dipertahankan.

\section{Kata Kunci: multikulturalisme; etnis; Gorontalo; Boalemo}

\section{PENDAHULUAN}

Negara Republik Indonesia merupakan Negara multikultural dimana masyarakat Indonesia terdiri dari berbagai keturunan yang terdiri dari berbagai etnik yang hidup di Negara Republik Indonesia. Kondisi ini merupakan rahmat bagi pemerintah Republik Indonesia apabila dari kehidupan keanekaragaman tersebut dapat hidup berdampingan secara damai. Oleh karenanya pemerintah Republik Indonesia menyadari akan bahaya ancaman dari kondisi tersebut. Sehingga sudah saatnya pemerintah mengupayakan kehidupan antar etnik dengan hidup rukun diantara sesama etnik tersebut sehingga tercipta keharmonisan diantara suku di Indonesia.

Provinsi Gorontalo merupakan salah satu daerah yang terdiri dari berbagai macam etnis, beberapa diantaranya ialah etnis lokal Gorontalo dan etnis Bali. Etnis lokal Gorontalo adalah sekumpulan masyarakat yang memiliki persamaan baik persamaan budaya, agama, adat, dan bahasa Gorontalo masyarakat lokal Gorontalo yang penduduknya mayoritas beragama islam. Sedangkan suku bangsa (etnis) Bali merupakan suatu kelompok manusia yang terikat oleh kesadaran akan kesatuan budaya, sedangkan kesadaran itu diperkuat oleh adanya kesamaan bahasa. Walaupun ada kesadaran yang demikian, namun kebudayaan Bali mewujudkan banyak variasi dan perbedaan setempat seperti perbedaan keyakinan agama. Masyarakat Bali di desa Tri Rukun mayoritas beragama Hindu yang telah lama terintegrasikan ke dalam kebudayaan Bali, dirasakan pula sebagai unsur yang memperkuat adanya kesadaran akan kesatuan itu. Oleh karena itu, kebudayaan etnis Bali tidak akan pernah terlepas dari dinamika sejarah Bali, yang memberikan warna pada setiap periode suatu peristiwa.

Desa Tri Rukun masyarakatnya yang beragam terdiri dari tiga etnis dan tiga agama yang berbeda seperti etnis Bali. Gorontalo, dan etnis Minahasa. Dengan mayoritas penduduk dari etnis Bali yaitu 885 Orang, kemudian Gorontao dengan jumlah penduduk 85 orang, dan terakhir Minahasa dengan jumlah 43 orang. Ketiga etnis etnis tersebut merupakan penduduk transmigrasi yang sekarang berada di Desa Tri Rukun. Dengan adanya berbagai macam etnis yang ada Gorontalo salah satunya ialah etnis Bali yang hidup dengan masyarakat lokal Gorontalo. Kedua etnis memiliki berbagai macam perbedaan yang saat ini satu sama lain hidup dalam keadaan yang saling berdekatan. Jika kedua kelompok etnis tersebut yaitu masyarakat lokal Gorontalo dan kelompok masyarakat yang beretnis Bali yang ada di Gorontalo tidak menunjukan hubungan emosional yang tidak harmonis, maka hal ini akan menyebabkan terjadi konflik antara etnis yang bisa menyebabkan runtuhnya ketahanan nasional Indonesia yang diakibatkan konflik internal negara Indonesia sendiri. 
Seperti halnya etnis Bali dan Gorontalo yang kedua etnis tersebut memiliki kebudayaannya masing-masing dan identik dengan agama yang dianutnya. Maka tidak bisa dinafikan bahwa antar masyarakat yang sesama etnis maupun yang berbeda etnis kadangkala terjadi gesekan atau hubungan emosional yang tidak sehat. Seperti konflik yang pernah terjadi di desa Tri Rukun yaitu konflik antar pemuda etnis Gorontalo dan pemuda dari ernis Bali yang disebabkan oleh minuman keras yang dikonsumsi para pemuda di desa tersebut. Selain dari konflik dikalangan pemuda tersebut, di desa Tri Rukun juga pernah terjadi pertentangan atau gesekan yang diakibatkan pernikahan antar dua agama yang berbeda yang mengharuskan salah satu dari pasangan tersebut meninggalkan agamanya dan berpindah keagama lain. jika konflik maupun pertentangan atau gesekan yang terjadi di Desa Tri Rukun tersebut tidak di atasi maka hal ini tentunya akan menjadi konflik yang lebih besar dan hingga memungkinkan terjadinya perang antar etnis atau suku yang berada di Desa Tri Rukun.

Berdasarkan penelusuran kembali di lokasi penelitian, konflik antar generasi muda, konflik asimilasi perkawinan antar etnis lokal dan etnis Bali di Desa Tri Rukun menurut ibu Ngiketut Dani mengatakan gesekan itu tidak pernah terjadi, karena warga masyarakat di Desa Tri Rukun yang dilihat dari namanya saja Tri Rukun. Tri artinya tiga etnis yang hidup rukun antar etnis lokal Gorontalo, etnis Minahasa dan etnis Bali. Bila terjadi konflik antar warga masyarakatnya diselesaikan melalui cara musyawarah.

Salah satu yang dapat mencegah konflik di desa Tri Rukun dapat diredam dengan penamaan desa Tri Rukun. Artinya dari pemberian nama desa tersebut sedikitnya telah membantu dalam mempererat hubungan antar etnis di desa Tri Rukun. Dan ini juga didukung oleh kearifan lokal etnis Bali dikenal dengan istilah :"Pari sade" yaitu suatu organisasi keagamaan yang selalu menjadi pegangan masyarakat dalam membina hubungan harmonis antar etnis lokal dengan etnis Bali. Organisasi ini selalu mengajarkan himbauan kepada masyarakatnya untuk selalu menghargai agama lain dan selalu hidup rukun antara sesama etnis. Melalui organisasi "Pari Sade" inilah etnis Bali dapat hidup rukun dengan etnis lokal etnis Gorontalo. Dan bukan hanya etnis lokal saja, dengan etnis Minahasa pun mereka dapat hidup rukun sesuai dengan nama desanya yakni Desa Tri Rukun.

Dengan melihat data awal yang telah diperoleh penelitian memfokuskan pada beberapa hal pada sebagai berikut :

a. Hubungan keharmonisan antar Etnis Gorontalo dan Etnis Bali di Desa Tri Rukun, Kecamatan Wonosari, Kabupaten Boalemo dilihat melalui indikator: kerjasama, kompetisi, konflik, akomodasi dan asimilasi.

b. Implikasi Interaksi sosial dilihat dari perspektif ketahanan nasional, dapat diukur melalui indikator sebagai berikut:

1) Indeks ketahanan nasional gatra ideologi dengan indikator sebagai berikut : relegiutas dan ketakwaan, toleransi, kesetaraan akses dan kesamaan hak dalam konteks kehidupan sosial.

2) Indeks ketahanan nasional gatra politik dengan indikator sebagai berikut : kapasitas pemerintah, keterwakilan, kepastian hukum, Ormas Pemuda, kapasitas kepartaian dan media masa.

3) Indeks ketahanan Nasional gatra ekonomi dengan indikator sebagai berikut : Pangan, Sandang, Perumahan, pertambahan kekayaan, kemiskinan, kesempatan kerja dan pemerataan. 
4) Indeks ketahanan nasional gatra sosial budaya dengan indikator sebagai berikut : Esklusi sosial (marginalisasi sosial atau bentuk dari tindakan penyingkiran dan pengucilan masyarakat), pendidikan, kesehatan, kerukunan sosial, ketertiban sosial dan perilaku sosial.

5) Indeks ketahanan nasional gatra pertahanan dan keamanan dengan indikator sebagai berikut : Gatra Pertahanan Negara tentang gangguan keamanan dan ketertiban sebagai berikut: gerakan separatisme, etno nasionalisme, etno sentrisme, ego sentrisme dan primordialisme. Gatra Keamanan Negara tentang kondisi terselenggaranya perlindungan, pelayanan dan pengayoman masyaarakat sebagai berikut : gesekan antar generasi muda, gesekan antar etnis (suku), gesekan keyakinan (agama), gesekan budaya (tradisi), gesekan ras, gesekan ideologi (partai politik, organisasi kemasyarakatan) dan gangguan keamanan dari luar.

c. Multikulturalisme dapat dilihat melalui indikator sebagai berikut : Prinsip egalitarian, prinsip kerjasama, prinsip toleransi, prinsip otonom dan prinsip akomodatif.

\section{METODE PENELITIAN.}

Data atau informasi dikumpulkan dalam bentuk deskripsi. Disamping itu penelitian ini lebih menekankan pada pengungkapan makna yang terkandung di dalam deskripsi data tersebut, karena itu penelitian ini menggunakan pendekatan metode penelitian kualitatif. Sehinnga dalam penelitian membangun Hubungan antara Entis Gorontalo dan Etnis Bali dalam perspektif ketahanan nasional (studi kasus di Kecamatan Wonosari) akan memperkuat ataupun menghasilkan suatu Teori baru dan Hipotesis berdasarkan fakta-fakta yang di temukan dilapangan. Penetapan lokasi penelitian didasarkan kepada pertimbangan desa Tri Rukun yang didiami oleh tiga etnis yakni etnis Bali mayoritas, etnis lokal Gorontalo dan etnis Minahasa yang berpotensi terjadi gesekan. Dengan pertimbangan itu maka penelitian difokuskan kepada Membangun keharmonisan antar etnis lokal Gorontalo dengan etnis Bali dalam mewujudkan negara multikulturalisme di Desa Tri Rukun Kecamatan Wonosari Kabupaten Boalemo Provinsi Gorontalo dan Implikasinya terhadap ketahanan wilayah.

\section{HASIL PENELITIAN DAN PEMBAHASAN.}

Cita-cita negara multikulturalisme di negara Republik Indonesia telah digaungkan oleh The Founding Pathers melalui keinginan untuk melaksanakan Nation State (konsep negara bangsa). Realisasi dari The Founding Pathers dalam mewujudkan negara multikulturalisme dapat kita gali melalui dasar negara Pancasila dan konstitusi sebagai sumber hukum tertinggi di negara kita pada pasal 1 ayat 1 UUD NRI 1945, pasal 18 UUD NRI 1945, pasal 27 UUD NRI 1945, pasal 28 UUD NRI 1945, Pasal 29 UUD NRI 1945 dan pasal 32 ayat 1 UUD NRI 1945. Dimana pasal-pasal ini merupakan penjabaran dari nilai-nilai Pancasila yang mengandung nilai multikulturalisme. Makna pasal 1 ayat 1 UUD NRI 1945 adalah mengharapkan negara Indonesia dalam menyikapi warga negara yang 
hetorogen berbeda suku, berbeda agama dan keyakinan, berbeda ras, berbeda pilihan politik dan berbeda tradisi dapat dipersatukan melalui pelayanan yang sama pemerintah pusat kepada warga negaranya. Demikian halnya pada pasal 18 UUD NRI1945 memberi makna bahwa pemerintah pusat harus memberikan otonomi kepada daerah dalam membangun daerahnya sesuai dengan kearifan lokal masing-masing daerah. Ini membuktikan bahwa prinsip negara multikulturalisme dengan prinsip memberikan hak otonomi sudah diatur oleh konstitusi. Selanjutnya pasal 27 UUD NRI 1945 sebagai realisasi dari prinsip egalitarian merupakan bagian dari prinsip multikulturalisme dimana pasal tersebut mengharapkan pemerintah bersikap adil pada semua warga negara dalam memperoleh kepastian hukum, pemerintah dalam menegakan hukum tidak bersikap diskriminatif pada warga negaranya. Begitu juga pada pasal 28 dan pasal 29 UUD NRI 1945 merupakan pelengkap dari prinsip negara multikulturalisme, memberi makna negara harus menghormati hak asasi dari warga negara. Dan dengan pasal 29 UUD NRI 1945 memberikan ruang bagi warga negara melaksanakan prinsip toleransi sebagai bagian dari prinsip negara multikulturalisme. Serta pasal 32 UUD NRI 1945 ayat 1 mengamanatkan negara memajukan kebudayaan nasional Indonesia ditengah peradaban dunia dengan menjamin kebebasan masyarakat dalam memelihara dan mengembangkan nilainilai budayanya.

Berdasarkan amanat tersebut, negara wajib berperan aktif menjalankan agenda pemajuan kebudayaan daerah menjadi kebudayaan nasional, sehingga setiap warga negara Indonesia wajib menghormati kebudayaan daerah sebagai bagian dari kebudayaan nasional. Berdasarkan legal standing di atas menunjukan The Founding Pathers memang bercita-cita dalam mendirikan negara Nation State dengan model negara multikulturalisme sebagai solusi dalam mewujudkan bentuk Negara Kesatuan Republik Indonesia.

Multilkulturalisme berhubungan dengan kebudayaan dan kemungkinan konsepnya dibatasi dengan muatan nilai atau memiliki kepentingan tertentu. Multikulturalisme pada dasarnya adalah pandangan dunia yang kemudian dapat diterjemahkan dalam berbagai kebijakan kebudayaan yang menekankan penerimaan terhadap realitas keagamaan, pluralitas, multikultural yang terdapat dalam kehidupan masyarakat. Multikulturalisme dapat juga dipahami sebagai pandangan dunia yang kemudian diwujudkan dalam kesadaran politik (Azyumardi Azra, 2007).

Multikulturalisme adalah suatu kondisi warga negara dari satu negara yang terdiri dari berbagai etnis, berbagai tradisi, berbagai keyakinan agama, ras yang berbeda dan bangsa yang berbeda serta memiliki pilihan ideologi politik berbeda, yang hidup dalam suatu negara dengan mengedepankan prinsip sikap egalitarian, sikap equality, sikap akomodatif, dan sikap toleransi yang tinggi dengan kebersamaan hidup dalam kedamaian tanpa ada sikap diskriminatif dari pemegang otoritas negara. Pengertian ini memberi makna yang mendalam dalam pengelolaan suatu negara untuk harus berhati-hati dalam pengelolaan negara yang terdiri dari berbagai bangsa, etnik, agama, berbeda ras serta berbeda pilihan ideologi politik Artinya negara harus bersikap adil tidak diskriminatif terhadap perbedaan yang ada pada warga negaranya tersebut.

Interaksi sosial dapat digunakan dalam melakukan evaluasi tentang kondisi keharmonisan dalam suatu daerah. Dimana bila interaksi sosial itu berjalan sesuai dengan tataran normal artinya kenormalan yang berlangsung 
dalam indikator interaksi sosial akan memberikan pengaruh kepada kondisi ketahanan wilayah disuatu daerah. Harapannya teori interaksi sosial dapat digunakan untuk mendorong kondisi keharmonisan hubungan antar warga negara yang berbeda keyakinan, berbeda ras, berbeda tradisi dsb..

Berdasarkan cita-cita dan harapan dalam membangun negara multikulturalisme perlu kita mengetahui definisi dari pengertian interaksi sosial menurut para ahli sosial. Diantaranya Susanto mendefinisikan pengertian interaksi sosial adalah hubungan antar manusia yang menghasilkan hubungan tetap dan pada akhirnya memungkinkan pembentukan struktur sosial. Hasil interaksi sangat ditentukan oleh nilai dan arti serta interpretasi yang diberikan oleh pihak-pihak yang terlibat dalam interaksi ini.

Setiap kelompok memiliki batasan-batasan yang jelas untuk memisahkan antara satu kelompok etnis dengan etnis lainnya. Menurut Koentjaraningrat, konsep yang tercakup dalam istilah etnis adalah golongan manusia yang terikat oleh kesadaran dan identitas akan kesatuan kebudayaan, sedangkan kesadaran dan identitas seringkali dikuatkan oleh kesatuan bahasa juga (Koentjaraningrat, 1982). Suku bangsa yang sering disebut etnik atau golongan etnik mempunyai tanda-tanda atau ciri-ciri karakteristiknya. Ciri-ciri tersebut terdiri dari (Bangun, 1988):

a. Memiliki wilayah sendiri

b. Mempunyai struktur politik sendiri berupa tata pemerintahan dan pengaturan kekuasaan yang ada

c. Adanya bahasa sendiri yang menjadi alat komunikasi dalam interaksi

d. Mempunyai seni sendiri (seni tari lengkap dengan alat-alatnya, cerita rakyat, seni ragam hias dengan pola khas tersendiri)

e. Seni dan teknologi arsitektur serta penataan pemukiman

f. Sistem filsafat sendiri yang menjadi landasan pandangan, sikap dan tindakan

g. Mempunyai sistem religi (kepercayaan, agama) sendiri.

Etnis lokal Gorontalo dikenal dengan tradisi adat bersendikan syaraa, syaraa bersendikan kitabullah. Inilah yang menjadi landasan masyarakat Indonesia didalam melakukan aktivitas. Dengan tradisi seperti ini masyarakat Gorontalo dikenal sebagai masyarakat agamis. Oleh karenanya apabila ada masyarakat lain selain etnis Gorontalo yang berprilaku tidak sesuai dengan kepribadian etnis lokal, akan menghadapi tantangan dalam melakukan interaksi sosial.

Ketahanan Nasional (Tannas) adalah kondisi dinamis bangsa Indonesia, yang berisi keuletan dan ketangguhan, yang mengandung kemampuan mengembangkan kekuatan nasional dalam menghadapi segala tantangan, ancaman, hambatan dan gangguan baik dari dalam maupun dari luar, untuk menjamin identitas, integritas, kelangsungan hidup bangsa dan negara, serta untuk mencapai perjuangan nasionalnya (Suradinata, 2005: 47, atau lihat Soemarsono dkk, 2001: 106).

Dalam pengertian tersebut, ketahanan nasional adalah kondisi kehidupan nasional yang harus diwujudkan. Kondisi tersebut harus terus diusahakan sejak dini, dibina dan bisa dimulai dari pribadi, keluarga, lingkungan, daerah, dan nasional. Proses berkelanjutan untuk mewujudkan kondisi tersebut dilakukan berdasar pemikiran geostrategi berupa konsepsi yang dirancang dan dirumuskan dengan memperhatikan kondisi bangsa dan konstelasi geografi Indonesia. Konsep inilah yang disebut ketahanan nasional (Soemarsono dkk, 
2001: 106). Jadi dapat disimpulkan bahwa ketahanan nasional adalah konsep geostrategi Indonesia. Adapun pada bagian ini akan dibahas lebih lanjut mengenai interaksi etnis di Gorontalo dan implikasinya terhadap ketahanan nasional.

\section{Hubungan Interaksi Antara Masyarakat Etnis Bali dan Etnis Gorontalo di Desa Tri Rukun.}

Bila kita menganalisis hasil temuan penelitian yang dibahas sesuai rumusan masalah dalam penelitian membuktikan bahwa hubungan interaksi antara masyarakat etnis Bali dengan etnis lokal Gorontalo di desa Tri Rukun pada posisi kualitatif sangat tangguh. Interaksi sosial dapat terjadi dalam berbagai bentuk. Interaksi yang dilakukan secara berulang akan menghasilkan proses sosial. Proses sosial adalah perilaku berulang yang dipergunakan oleh seseorang dalam berinteraksi dengan orang lain (interaksi sosial). Horton (1983:74) menyebutkan 5 (lima) kemungkinan proses sosial, antara lain kerjasama, persaingan, konflik, akomidasi dan asimilasi.

Berdasarkan teori interaksi sosial tersebut akan dijelaskan kondisi interaksi sosial bagi warga masyarakat desa Tri Rukun 5 bentuk interaksi yaitu:

1) Interaksi dalam bentuk Kerjasama antar etnis di Desa Tri Rukun. Dalam bentuk Kerjasama dibuktikan dengan dilasanakan kegiatan gotong royong, dan selain Kerjasama juga terjadi dalam bidang kebudayaan yaitu pada pembuatan sampai pawai Ogoh-ogoh ketika Nyepi, dan juga Kerjasama pembuatan alikusu ketika menyambut hari raya Idhul Fitri dilakukan secara bersama antar warga etnis Bali dengan etnis lokal Gorontalo.

2) Interaksi dalam bentuk persaingan positif antara masyarakat etnis yang berada di Desa Tri Rukun. Di desa Tri Rukun persaingan antar etnis lokal Gorontalo dengan etnis Bali tidak terjadi justru yang terjadi adalah warga etnis Bali dan etnis lokal Gorontalo dalam membuka usaha dalam menunjang ekonomi masyarakatnya dilakukan secara bersama, misalnya etnis Bali buka usaha pertokoan warga masyarakat etnis lokal menjadi konsumernya, demikian juga bila warga etnis lokal membuka usaha kioskios warga etnis Bali bersedia menampung atau melayani pembelian barang dagangan dari etnis lokal. Kehidupan usaha perdagangan tidak terjadi gesekan antar etnis Bali dan etnis lokal. Begitu juga dalam melaksanakan usaha pertanian, perkebunan dan peternakan semua dilaksanakan dengan prinsip saling bekerja sama antar etnis lokal Gorontalo dengan etnis Bali. Dapat dikatakan suasana multikulturalisme di desa Tri Rukun terbangun atas dasar kesadaran warga masyarakatnya dan didukung oleh pemerintah desa yang selalu mensosialisasikan kehidupan multikulturalisme melalui organisasi FKUB (Forum Komunikasi Umat Beragama) dan melalui organisasi karana taruna di desa Tri Rukun.

3) Interaksi dalam bentuk Konflik antara masyarakat etnis yang berada di Desa Tri Rukun tidak ditemukan konflik antar warga masyarakat baik gesekan antar pemuda, gesekan antar budaya, gesekan antar pilihan politik dan bahkan gesekan antar keyakinan beragama, semuanya berjalan dengan normal. Kalaupun ada dapat diselesaikan secara musyawarah oleh kepala desa bersama tokoh-tokoh masyarakat dan tokoh-tokoh agama dan tidak terjadi konflik horizontal dan konflik vertikal sebagaimana yang terjadi di daerah Kabupaten Poso Sulawesi Tengah dan Provinsi Maluku. 
4) Interaksi dalam bentuk asimilasi masyarakat Etnis yang berada di Desa Tri Rukun. Bila melihat proses asimilasi di desa Tri Rukun warga masyarakat etnis Bali dan etnis lokal Gorontalo pada saat pelaksanaan mengarak ogohogoh warga etnis lokal Gorontalo terlibat dalam kegiatan etnis Bali. Demikian pula sebaliknya warga masyarakat etnis Bali terlibat dalam tradisi etnis lokal Gorontalo dalam melaksanakan kegiatan malam pasang lampu atau tradisi Tombilatohe. Dan bahkan pelaksanaan kegiatan hari-hari besar keagamaan seperti perayaan hari raya Idul Fitri dan hari Natal ketiga etnis yang ada di desa Tri Rukun etnis Bali, etnis lokal Gorontalo dan etnis Minahasa saling mengunjugi kepada mereka (etnis) yang merayakan harihari besar keagamaan tersebut.

5) Untuk proses akulturasi terjadi pada warga etnis Bali dan etnis lokal Gorontalo yaitu dengan melangsungkan pernikahan antar etnis Bali dengan etnis lokal Gorontalo pernikahan ini tidak menimbulkan benturan tradisi, benturan agama dan benturan etnis semuanya berjalan normal. Dan ini semuanya terjadi pada warga etnis Bali di desa Tri Rukun kecamatan Wonosari Kabupaten Boalemo.

\section{Implikasi membangun Keharmonisan Antar Etnis Lokal Gorontalo dengan Etnis Bali dalam mewujudkan negara multikulturalisme terhadap ketahanan Wilayah di Desa Tri Rukun Kecamatan Wonosari Kabupaten Boalemo Provinsi Gorontalo.}

Implikasi selalu menjadi bagian yang diukur dari penerapan model negara multikulturalisme di dalam membangun hubungan harmonis antar etnis lokal Gorontalo dengan etnis Bali. Untuk mengetahui implikasi dari penerapan model negara multikulturalisme sebaiknya kita menganalisanya berdasarkan teori ketahanan nasional didalam mengukur indeks ketahanan wilayah di desa Tri Rukun kecamatan Wonosari. Hal ini ditunjukan oleh variabel indeks ketahanan wilayah sebagai berikut dibegi menjadi lima demensi yaitu, dimensi ideologi, dimensi politik, dimensi ekonomi, dimensi sosial dan budaya serta dimensi kemamanan.

Pada dimensi ideologi warga masyarakat desa Tri Rukun dapat diukur melalui indikator indeks ketahanan wilayah. Aspek pertama adalah aspek regigius dan ketakwaan. Warga masyarakat desa Tri Rukun sangat menjunjung tinggi pelaksanaan kegiatan ritual keagamaan masing-masing etnis artinya kegiatan religiutas berjalan normal tanpa saling menganggu antar etnis yang satu dengan etnis lainnya. Buktinya di desa Tri Rukun kehidupan beragama dibuktikan adanya tempat suci masing-masing agama telah berdiri dan warganya melakukan peribadatan saling mendukung dalam melaksanakan kegiatan ritual keagamaan.

Selanjutnya adalah Sikap toleransi. Pada saat melaksanakan peribadatan etnis lokal Gorontalo dan etnis Minahasa menghormati dan mentaati peraturan ketika umat Hindu etnis Bali merayakan hari Nyepi. Hal ini dikemukakan oleh para informan penelitian kedua etnis yang ada di desa Tri Rukun melaksanakan dan menaati peraturan penerapan hari Nyepi, dimana warga masyarakatnya dilarang melakukan aktivitas yang dapat mengganggu bagi kekhusuan umat Hindu melaksanakan ritual Nyepi. Etnis Bali pun masih sangat toleran dengan etnis lokal Gorontalo dengan etnis Minahasa dalam melakukan aktivitas dengan memberikan kelonggaran beraktivitas tidak seperti di Provinsi Bali, semua warga 
masyarakat tidak dapat beraktivitas demi menaati aturan pelaksanaan hari Nyepi, yang terpenting tidak mengganggu kegiatan ritual Nyepi. Dan ini dipatuhi oleh warga masyarakat di desa Tri Rukun.

Aspek ketiga yaitu kesetaraan akses. Dalam menikmati sumber potensi ekonomi maupun sumber daya alam, pelayanan pendidikan, pelayanan kesehatan pemerintah desa Tri Rukun mendistribusikan didasarkan pada kebutuhan warga masyarakatnya, tidak melihat pada komposisi etnis mayoritas. Semuanya mendapatkan bantuan dan pemanfaatan sarana diberikan kepada ketiga etnis yang ada di desa Tri Rukun.

Aspek yang tidak kalah penting dalam ideologi adalah kesamaan hak dalam konteks kehidupan sosial. Warga masyarakat desa Tri Rukun memiliki hak yang sama dalam segala hal, tanpa ada yang diperlakukan diskriminatif oleh warga masyarakat mayoritas maupun pemerintah desa. Hal ini sesuai fakta dan informasi informan penelitian bahwa ketiga etnis dalam struktur pemerintahan desa terisi dari ketiga etnis yang ada yakni etnis Bali, etnis lokal Gorontalo dan etnis Minahasa. Hal ini menunjukan bahwa pada struktur pemerintahan desa pun mengakomodir model negara multikulturalisme.

Dimensi kedua yang menjadi indikator indeks ketahanan wilayah adalah dimensi politik. Adapun dimensi ini dapat diukur melalui enam variabel utama. 1) Kapasitas pemerintah. Pemerintah desa Tri Rukun selalu berpihak kepada prinsip model negara multikulturalisme seperti prinsip egalitarian, prinsip kerjasama, prinsip toleransi, prinsip otonom dan prinsip akomodatif sehingga kehadiran pemerintah desa dianggap melindungi semua kepentingan etnis yang ada di desa Tri Rukun. 2) Keterwakilan, indikator keterwakilan dilaksanakan oleh pemerintah desa Tri Rukun dengan menempatkan ketiga etnis yang ada sebagai bagian terpenting dalam struktur pemerintahan desa. Dimana dalam struktur pemerintahan desa Tri Rukun ketiga etnis masuk dalam aparatur desa Tri Rukun. 3) Kepastian hukum yaitu warga masyarakat desa Tri Rukun bila ada permasalahan selalu diselesaikan secara musyawarah di kantor desa dan selalu berakhir dengan kedamaian, sehingga asas kepastian hukum dirasa oleh warga masyarakat desa Tri Rukun telah sesuai dengan penyelesaian masalah yang dihadapi. 4) Ormas Pemuda yang diarahkan melalui organisasi Karang Taruna maupun organisasi keagamaan seperti "Pari Sade" dengan tujuan didalam mewujudkan keharmonisan diantara etnis yang ada di desa Tri Rukun. 5) Kapasitas kepartaian dimana warga masyarakat desa Tri Rukun diberikan kebebasan dalam memilih pilihan politiknya tanpa intervensi dari pemerintah desa. 6) Media massa yang dapat diakses dan tidak memberikan pengaruh negatif pada hubungan antar etnis, seperti informasi dari luar tentang konflik antar agama di negara lain tidak memberikan pengaruh negatif pada hubungan antar etnis di desa Tri Rukun.

Selanjutnya dimensi ekonomi menjadi faktor penting yang menjadi fokus analsis. Pada dimensi ekonomi warga masyarakat desa Tri Rukun dapat diukur melalui indikator indeks ketahanan wilayah antara lain 1) Pangan yaitu kebutuhan pangan warga masyarakat desa Tri Rukun sangat terpenuhi karena warga masyarakat transmigrasi dengan etos kerja yang tinggi membuat ketahanan pangan di desa Tri Rukun sangat tangguh dalam mencukupi pangan warganya. 2. Sandang merupakan kebutuhan sandang bagi warga masyarakat desa Tri Rukun sangat terpenuhi dimana seluruh warga masyarakatnya dapat mencukupi untuk membeli pakaian dalam bentuk dan corak /model apapun 
dapat disanggupi karena desa Tri Rukun sudah pada level desa swakarya sebagai desa prasejahtera menuju status desa swasembada atau sebagai desa berkembang. Desa swasembeda biasa disebut sebagai desa maju atau desa berkembang. Masyarat desa ini sudah mampu memanfaatkan dan mengembangkan sumber daya yang ada untuk kegiatan pembangunan desa. Tingkat pendidikan dan perekonomian masyarakat lebih maju dibandingkan tingkatan desa lain dan sudah bisa mengembangkan ide yang dimiliki. Mau berpartisipasi dan memiliki pola pemikiran yang lebih modern. 3. Papan atau perumahan. Warga masyarakat desa Tri Rukun memiliki rumah yang sudah layak huni bahkan ada beberapa rumah warga masyarakat sudah sangat elit yang dimiliki oleh etnis Bali. Di desa Tri Rukun tidak ada lagi warga masyarakatnya yang tinggal pada rumah yang tidak layak huni, semuanya sudah memenuhi syarat untuk ditinggali warga masyarakatnya.

Selain ketiga faktor diata penting juga untuk memeperhatikan Pertambahan kekayaan warga. Warga transmigrasi di desa Tri Rukun mengalami proses perubahan yang luar biasa dimana dari awal mereka tinggal hanya difasilitasi rumah papan dengan ukuran yang sangat sederhana dan diberikan lahan masing-masing 1 ha dan untuk lahan pendirian rumah seukuran rumah sederhana, dan lahan pekarangan sehingga total lahan per rumah tangga seluas 2 ha. Saat ini telah berubah sebagaimana yang ada saat ini, rumahnya sudah permanen dan ada pertambahan lahan yang dimiliki oleh warga transmigrasi. Sehingga desa Tri Rukun menyumbang Pajak Bumi dan bangunan (PBB) untuk setiap tahunnya lebih kurang Rp.25.000.000,00 pertahun.

Selanjutnya adalah indikator kemiskinan. Demi mewujudkan negara multikulturalisme disuatu wilayah yang harus diperhatikan oleh pemerintah daerah adalah bagaimana menekan angka kemiskinan. Bila angka kemiskinan disuatu wilayah sangat tinggi, maka secara tidak langsung akan mempengaruhi ketahanan wilayah disuatu daerah. Mengapa karena kemiskinan sumber dari gesekan sosial, dimana kemiskinan akan banyak memberikan dampak sosial misalnya penjarahan kepada warga masyarakat yang memiliki kemampuan ekonomi, kemiskinan bisa saja memicu kerusuhan sosial dsb. Artinya bila ingin mewujudkan negara multikultural, maka yang harus diperhatikan oleh pemerintah adalah menekan angka kemiskinan diwilayahnya.

Menurut Kuncoro (2004), pengukuran kriteria garis kemiskinan di indonesia diukur untuk kemiskinan absolut, institusi pemerintah yang biasa menetapkan kriteria garis kemiskinan yaitu BPS (1994) kiteria kemiskinan menggunakan ukuran uang rupiah yang dibelanjakan perkapita sebulan untuk memenuhi kebutuhan hidup minimum makanan dan bukan makanan.

Bagi warga masyarakat desa Tri Rukun khususnya warga Transmigrasi indeks kemiskinan tidak ditemukan lagi yang pendapatannya menurut IDB \$ 2 perhari, pendapatan warga transmigrasi di desa Tri Rukun sudah di atas klasifikasi kemiskinan sebagaimana yang dijadikan sebagai dasar dalam menentukan kemiskinan. Mengapa banyak pendapatan warga Transmigrasi di desa Tri Rukun bila dilihat PDB rata-rata warga masyarakatnya memiliki pendapatan di atas garis kemiskinan. Sehingga itu desa Tri Rukun ditetapkan sebagai desa swakarya dan saat ini menuju status desa swasembada atau desa berkembang / desa maju. Kesempatan kerja juga dapat dikategorikan baik Di desa Tri Rukun dimana warga diberi lahan pemerintah daerah seluas 2 ha bagi penduduk transmigrasi sehingga warga masyarakatnya memiliki peluang usaha 
yang sama dalam mengembangkan lahannya. Pemerintah desa juga selalu mendistribusikan bantuan sosial dari pemerintah daerah kepada semua warga desa Tri Rukun dengan mengedepankan sikap pemerataan kepada siapa saja warga desanya yang membutuhkan bantuan sosial dari pemerintah daerah yang penyalurannya dilakukan oleh pemerintah desa tanpa melihat perbedaan etnisnya.

Dimensi kedua yang menjadi indikator indeks ketahanan wilayah adalah dimensi sosial budaya. Pada dimensi sosial budaya warga masyarakat desa Tri Rukun dapat diukur melalui indikator indeks ketahanan wilayah antara lain esklusi sosial, pendidikan, kesehatan, ketertiban sosial, kerukunan sosial dan perilaku sosial.

Di desa Tri Rukun tidak ditemukan sikap esklusi sosial, semua warga masyarakat dari ketiga etnis yaitu etnis Bali, etnis lokal Gorontalo dan etnis Minahasa tidak ada yang dimarginalisasi baik itu oleh pemerintah desa maupun oleh etnis mayoritas di desa Tri Rukun. Adapun dalam bidang pendidikan di desa Tri Rukun masih ada warganya yang tidak tamat pendidikan dasar, namun upaya pemerintah desa bagi warganya yang putus sekolah didorong dan dibantu lewat dana desa dalam meningkatkan kualitas pendidikan melalui pendidikan paket A, B dan paket C.

Selanjutnya di bidang kesehatan, bagi warga masyarakat desa Tri Rukun dalam pelayanan kesehatan didukung oleh pusat pelayanan kesehatan masyarakat pembantu (Pustu) dan tenaga medis bidan desa. Untuk layanan Puskesmas tidak terlalu jauh dari desa Tri Rukun. Tetapi temuan penelitian angka harapan hidup di desa Tri Rukun masih di bawah 75 tahun. Artinya pemerintah desa harus lebih maksimal dalam meningkatkan angka harapan hidup melalui sosialisasi kesehatan akan pentingnya pelayanan medis bagi kesehatan masyarakat. Mengapa demikian karena masih ada sebagian kecil masyarakat yang masih percaya dengan pengebatan tradisional sifatnya mistik atau juga pola dan gaya hidup masyarakat yang bertentangan dengan kesehatan.

Di desa Tri Rukun sampai dengan saat ini masih terjaga kerukunan sosial antar etnis lokal Gorontalo dengan etnis Bali dan tidak ditemukan konflik baik itu konflik secara horizontal maupun konflik secara vertikal. Di desa Tri Rukun sangat dijunjung tinggi ketertiban sosial antar etnis lokal Gorontalo dengan etnis Bali ini ditunjukan pada kegiatan perayaan hari Nyepi di desa Tri Rukun warga etnis lokal sangat menjunjung tinggi larangan-larangan yang dapat mengganggu kekhusuan umat Hindu etnis Bali melaksanakan peribadatan Nyepi. Demikian sebaliknya bila etnis lokal melakukan aktivitas peribadatan tidak pernah dihalang-halangi oleh warga etnis Bali dalam melakukan kegiatan ritual keagamaan.

Perilaku sosial warga masyarakat desa Tri Rukun menunjukan sikap multikulturalisme karena semua aktivitas dilaksanakan dengan prinsip egalitarian, mengedepankan sikap toleransi, sikap kerja sama antar etnis, prinsip otonom dan sikap akomodatif pemerintah desa kepada semua warganya.

Dimensi terakhir adalah dimensi pertahanan. Pada dimensi pertahanan warga masyarakat desa Tri Rukun dapat diukur melalui indikator indeks ketahanan wilayah. Indikator ini terkait dengan sikap warga dalam menanggapi sikap yang dapat memecak belah persatuan. 
Gerakan separatisme yang merupakan gangguan pertahanan di desa Tri Rukun tidak ditemukan, semua warga masyarakatnya telah mengantisipasi gerakan yang akan memecah belah antar etnis melalui sosialisasi FKUB (Forum Komunikasi Umat Beragama) yang dilaksanakan pemerintah desa. Sejalan dengan hal terdrbut sikap etno nasionalisme tidak ditemukan karena warga mayoritas etnis Bali tidak merasa superior dalam segala hal. Demikian halnya dengan etnis lokal Gorontalo tidak merasa sebagai tuan tanah lalu memperlakukan sikap negatif kepada etnis Bali. Sikap etno sentrisme juga tidak ditemukan pada hubungan interaksi antar etnis lokal Gorontalo dengan etnis Bali di desa Tri Rukun. Semua warga masyarakat desa Tri Rukun lebih mengedepankan sikap egalitarian kepada semua etnis yang ada di desa Tri Rukun.

Selanjutnya sikap egosentrisme tidak ditemukan karena semua kegiatan di desa Tri Rukun dilaksanakan secara gotong royong dalam melakukan kegiatan ritual maupun kegiatan usaha perdagangan, usaha pertanian, usaha perkebunan dan usaha peternakan. Sikap primordialisme dikalangan warga masyarakat desa Tri Rukun juga tidak pernah ada, karena warga masyarakatnya menghargai hak-hak politik warganya serta hak dalam memperoleh kesempatan kerja, pemilihan jodoh pun warga masyarakat desa Tri Rukun tidak mempermasalahkan.

Pada dimensi keamanan warga masyarakat desa Tri Rukun dapat diukur melalui indikator indeks ketahanan wilayah dengan melihat gesekan-gesekan yang terjadi antar-warga. Yang pertama adalah gesekan antar-pemuda. Gesekan antar generasi muda warga etnis Bali dengan etnis lokal Gorontalo tidak pernah terjadi di desa Tri Rukun, kalaupun ada gesekan semuanya diselesaikan melalui musyawarah atau melalui organisasi Para Sade bagi warga etnis Bali.

Gesekan antar etnis juga tidak pernah terjadi antar etnis lokal Gorontalo dengan etnis Bali. Kehidupan interaksi sosial berjalan normal dan sampai dengan saat ini desa Tri Rukun ketiga etnis yaitu etnis Bali, etnis lokal Gorontalo dengan etnis Minahasa hidup berdampingan dengan menjalankan prinsip negara multikulturalisme. Sejalan dengan hal tersebut gesekan keyakinan beragama tidak pernah terjadi di desa Tri Rukun, karena warga masyarakatnya sudah memiliki sikap multikuralisme dalam melakukan interaksi sosial. Gesekan budaya tidak pernah terjadi bahkan kedua etnis saling mendukung melaksanakan tradisi antar etnis, misalnya mengarak Ogoh-Ogoh etnis lokal Gorontalo sama-sama melakukannya denga etnis Bali. Demikian halnya dengan pemasangan lampu Tombilatohe warga etnis Bali pun ikut melaksanakan pemasangan lampu di rumahnya dan di kantor desa.

Bagi warga etnis lokal Gorontalo dengan etnis Bali tidak pernah ada karena kedua etnis ini memiliki persamaan ras yang sama, keduanya berasal dari ras mongoloid, sehingga mempermudah dalam membangun negara multikulturalisme. Gesekan ideologi juga tidak pernah terjadi di desa Tri Rukun, kegiatan kepartaian dan organisasi kemasyarakatan dilaksanakan dengan prinsip otonom.

Adapun terkait dengan gangguan keamanan eksternal dapat diantisipasi oleh warganya dan pemerintah desa melalui Forum Komunikasi Umat Beragama (FKUB) dan organisasi Karang Taruna yang selalu mensosialisasikan prinsipprinsip multikulturalisme dalam setiap aktivitas masyarakatnya. 
Masyarakat desa Tri Rukun sudah melaksanakan prinsip-prinsip multikulturalisme. Warga masyarakat desa Tri Rukun sangat egalitarian didalam melaksanakan interaksi antar sesama etnis, baik etnis Bali mayoritas dengan etnis lokal Gorontalo hubungannya sangat baik, karena semua etnis mengedepankan sikap egalitarian dalam melakukan segala aktivitas di desa. Kerja sama antar etnis Bali, etnis lokal Gorontalo dan etnis Minahasa selalu terjalin diantara ketiga etnis bila melakukan kegiatan-kegiatan sosial. Prinsip bekerjasama dengan etnis yang berbeda inilah yang membuat desa Tri Rukun sampai dengan saat ini tidak mengalami gesekan sosial.

Hubungan antar agama dari ketiga etnis sangat toleran, ini ditunjukan hasil jawaban informan penelitian di desa Tri Rukun masing-masing etnis menghargai keyakinan beragama masing-masing etnis. Pemerintah desa Tri Rukun memberikan kebebasan warga masyarakatnya dalam menjalankan segala aktivitas yang berhubungan dengan kegiatan yang dapat menciptakan kesejahteraan bagi masyarakatnya. Demikian juga dengan pilihan politik pemerintah desa tidak pernah mengintervensi warganya. Pemerintah desa Tri Rukun selalu mengakomodir pendapat warganya selama masih dalam kepentingan membangun desa Tri Rukun dengan tidak melihat dari mana asal sukunya, agamanya serta pilihan politiknya.

\section{PENUTUP}

\section{Kesimpulan}

Kondisi hubungan keharmonisan antar etnis lokal Gorontalo dan etnis Bali berdasarkan hasil penelitian menunjukan bahwa ketahanan wilayah desa Tri Rukun secara indeks kualitatif pada posisi sangat tangguh. Penetapan indeks tersebut di dasarkan pada indikator kerjasama, dimana warga masyarakat desa Tri Rukun antar etnis lokal Gorontalo dengan etnis Bali saling mendukung dalam semua aktivitas kesehariannya. Sehingga tidak ditemukan warga etnis Bali dan etnis lokal Gorontalo yang bersikap individualisme dalam melaksanakan kegiatan di desa Tri Rukun. Begitu pula dengan indikator asimilasi, dimana berdasarkan hasil penelitian proses asimilasi antar enis lokal Gorontalo dengan etnis Bali berjalan normal dimana warga etnis lokal Gorontalo terlibat dalam kegiatan ritual etnis Bali hal ini dapat dinilai dari hasil wawancara menunjukan etnis lokal Gorontalo dalam pelaksanaan kegiatan ritual Ogoh-Ogoh ikut dalam mengarak kegiatan tersebut. Demikian halnya dengan etnis Bali yang terlibat langsung dalam kegiatan ritual keagamaan etnis lokal dimana etnis Bali ikut memasang lampu Tombilatohe pada akhir bulan suci Ramadhan. Bentuk kegiatan ini menunjukan bahwa proses asimilasi di desa Tri Rukun berjalan dengan normal karena tidak terjadi gesekan diantara tradisi etnis tersebut. Demikian juga dengan indikator asimilasi, kompetisi, akulturasi. Implikasi membangun keharmonisan antar etnis lokal Gorontalo dengan etnis Bali dalam mewujudkan negara multikulturalisme di desa Tri Rukun Kecamatan Wonosari Kabupaten Boalemo Provinsi Gorontalo terhadap ketahanan wilayah ditemukan melalui hasil jawaban informan penelitian yang menunjukan implikasi dari indeks ketahanan wilayah di desa Tri Rukun pada posisi kualitatif sangat tangguh. 


\section{Saran}

Berdasarkan kesimpulan di atas tentang membangun keharmonisan antar etnis lokal Gorontalo dengan etnis Bali dalam mewujudkan negara multikulturalisme di desa Tri Rukun kecamatan Wonosari dapat direkomondasikan hal-hal sebagai berikut :

1. Hubungan keharmonisan antar etnis lokal Gorontalo dengan etnis Bali dalam mewujudkan negara multikulturalisme yang sudah pada posisi sangat tangguh dapat dipertahankan oleh warga masyarakat desa Tri Rukun dan pemerintah desa serta harus menjadi perhatian pemerintah daerah kabupaten Boalemo bekerjasama dengan pemerintah kecamatan selalu mengawasi potensi yang akan menimbulkan gesekan sosial yang akan mempengaruhi ketahanan wilayah di daerah kabupaten Boalemo melalui bentuk penerapan prinsip model negara multikulturalisme.

2. Implikasi dari cita-cita membangun keharmonisan antar etnis lokal Gorontalo dengan etnis Bali demi mewujudkan negara multikulturalisme terhadap ketahanan wilayah pada posisi sangat tangguh untuk dapat dijaga dan dipertahankan stabilitas keamanannya, agar supaya roda perekonomian di desa Tri Rukun berjalan dengan baik.

3. Prinsip-prinsip negara multikulturalisme sikap egalitarian, sikap toleransi, sikap kerjasama, sikap otonom dan sikap akomodatif dapat dijadikan sebagai landasan dalam melaksanakan semua program pemerintahan di desa Tri Rukun. Supaya pemerintah desa Tri Rukun tidak akan mengalami turbolensi dalam menciptakan stabilitas desa yang akan berpengaruh kepada ketahanan wilayah. Bila mengabaikan prinsip-prinsip negara multikulturalisme sudah dipastikan akan terjadi turbolensi dan akan menggangu ketahan wilayah desa Tri Rukun.

4. Pemerintah daerah kebupaten Boalemo diharapkan untuk komitmen dalam menjalankan model negara multikulturalisme mulai ketingkat pemerintahan Kecamatan sampai ketingkat pemerintahan desa, sehingga dapat berimplikasi terhadap ketahanan desa di seluruh desa dilingkungan pemerintahan kabupaten Boalemo, yang natinya akan menjadi penentu bagi ketahanan wilayah pemerintah daerah Kabupaten Boalemo Provinsi Gorontalo.

\section{DAFTAR PUSTAKA}

Abu Ahmadi, Haji.2007. Psikologi Sosial. Jakarta, Rineka Cipta

Amanda, A. (2016). Peran Agensi Budaya dan Praktik Multikulturalisme di Perkampungan Budaya Betawi (PBB) Setu Babakan. Jurnal Pemikiran Sosiologi, 3(2), 40-58.

Andriani Duri, Dkk. 2013. Metode Penelitian. Banten. Universitas Terbuka Irhandayaningsih, A. (2012). Kajian Filosofis Terhadap Multikulturalisme Indonesia. Humanika, 15(9).

Kymlicka, Will. 2011 “Kewarganegaraan Multikultural”. Penerbit LP3ES.

Lukum, Roni. 2010. Pendapat Masyarakat Terhadap Pembagunan Manusia Di Kabupaten Bone Bolango Dan Implikasinya Terhadap Ketahanan Wilayah. Gorontalo. UNG 
Mahyuddin, M. (2019). Modal Sosial dan Integrasi Sosial: Asimilasi dan Akulturasi Budaya Masyarakat Multikultural di Polewali Mandar, Sulawesi Barat. KURIOSITAS: Media Komunikasi Sosial dan Keagamaan, 12(2), 111122.

Sugiyono. 2009. Memahami Penelitian Kualitatif. Bandung. ALFABETA

Suparlan, P. (2014). Menuju masyarakat Indonesia yang multikultural. Antropologi Indonesia. 